\title{
KEMENANGAN KOTAK KOSONG (KOKO) DALAM PEMILIHAN KEPALA DAERAH
}

\author{
Roy Marthen Moonti \\ Fakultas Hukum Universitas Gorontalo \\ roymoonti16@gmail.com
}

\begin{abstract}
Abstrak
Tulisan ini bertujuan untuk mengetahui fenomena kotak kosong dan untuk mengetahui kemenangan kotak kosong dalam pemilihan kepala daerah. Jenis penelitian yang digunakan yaitu penelitian yuridis normative yaitu pendekatan terhadap permasalahan dilakukan dengan mengkaji ketentuan mengenai kemenangan kotak kosong dalam pemilihan kepala daerah. Hasil penelitian menunjukkan bahwa fenomena kotak kosong sudah bukan menjadi hal yang langka lagi karena di beberapa daerah sudah banyak bermunculan. Hal ini teradi karena proses demokrasi yang belum merata karena dari data yang ada beberapa daerah yang melangsungkan pemilihan kepala daerah itu kekurangan calon pemimpinan dan kemenangan kotak kosong dalam pemilihan kepala daerah itu disebabkan oelh beberapa patai politik yang berada didaerah belum mampu untuk menyiapkan kader yang akan dipersiapkan dalam pemilihan kepala daerah serta syarat dukungan perseorangan yang susah untuk dipenuhi oleh para kontestaan.
\end{abstract}

Kata Kunci : Kotak Kosong, Pemilihan Kepala Daerah.

\section{PENDAHULUAN}

Pemilihan umum (pemilu) juga sebagai salah satu sarana untuk penyaluran aspirasi rakyat terhadap pemerintahan dengan diadakannya pemilu. Dewasa ini yang tidak kalah menariknya adalah potensi persoalan hanya satu pasangan calon tanpa pasangan calon lain sebagai 'lawan'. Potensi satu pasangan calon dapat diidentifikasi dengan indikator tidak terdapatnya figur-figur yang mendaftar sebagai bakal pasangan calon perseorangan, adanya bakal pasangan calon yang menghimpun dan mendapat rekomendasi partai politik atau gabungan partai politik melebihi jumlah kursi yang dipersyaratkan atau jumlah kursi partai politik atau gabungan partai politik yang tersisa tidak mencukupi syarat untuk mengusung pasangan calon. Seyogyanyauproses pencalonan yang berujung pada calon tunggal merupakan kondisi kedaruratan. Sebuah kondisi ketika sudah benar- benar tidak ada calon lain yang layak. Fenomena calon tunggal berakar dari kegagalan partai politik menjalankan fungsi pengkaderan. Parpol juga cenderung bersikap pragmatis dan memilih calon instan atau populer karena takut kalah. ${ }^{14}$

Pemilihan Kepala Daerah (Pilkada) serentak 2018 berjalan aman, damai, dan lancar. Ada hal menarik dan unik dari kontestasi tersebut, yakni menangnya kotak kosong melawan calon tunggal. Salah satunya di Makassar, Sulawesi Selatan. Hasil ini pun diakui bersejarah sepanjang perjalanan Pilkada langsung sejak 2015, 2017, hingga tahun ini. ${ }^{15}$

Sejarah panjang bangsa ini dalam melangsungkan pemilihan kepala daerah sepertinya tercederai dengan munculnya sebuah fenomena kotak kosong (koko) yang oleh banyak orang dianggap sebagai sebuah keajaiban dalam proses berdemokrasi, kenapa tidak karena banyak kalangan masyarakat menilai bahwa jika kandidat kepala daerah yang melawan kotak kosong sudah bisa dipastikan $75 \%$ akan mengalami kemenangan, akan tetapi ini semua berbanding terbalik dengan prediksi masyarakat. Dari pelaksanaan Pilkada serentak sebelumnya yang terjadi ditahun 2015, 2017 belum ada kotak kosong yang bisa menang didalam perhelatan. Fenomena ini baru terjadi di Pilkada serentak yang dilaksanakan pada tahun 2018. Apa yang terjadi sebenarnya dengan bangsa ini sehingga hal ini sampai terjadi, tentunya hal didasari oleh regulasi yang tetapkan oleh pemerintah yang memperbolehkan calon tunggal untuk dapat berlaga di Pilkada.

Fenomena kotak kosong memang dimungkinkan terjadi bila peserta Pilkada adalah calon tunggal. Dalam UU Nomor 10 Tahun 2016 Tentang Pilkada telah mengatur mekanisme pilkada yang hanya diikuti calon tunggal. Dalam Pasal 54D diatur, pemenang pilkada dengan calon tunggal harus memperoleh suara lebih dari 50 persen

\footnotetext{
${ }^{14}$ Siti Dwi Puspita sari. Peran AKDPP (Aliansi Kawal Demokrasi Pilkada Pati) dalam Kemenangan Kotak Kosong di Desa Gajahmati dan Desa Maitan pada Pilkada Kabupaten Pati Tahun 2017. Jurusan Ilmu Pemerintahan Fakutas Ilmu Sosial dan Ilmu Politik Universitas Diponegoro. h. 2.

15 Mohamad Rizal. Kemenangan Kotak Kosong jadi Sejarah Baru di Pilkada http://pilkada.metrotvnews.com/news-pilkada/DkqL198b-kemenangan-kotak-kosong-jadi-sejarah-baru-dipilkada. Diakses pada tanggal 23 September 2018.
} 
suara sah. Apabila suara yang diperoleh tidak mencapai lebih dari 50\%, maka pasangan calon yang kalah boleh mencalonkan lagi dalam pemilihan berikutnya. Pada pasal 25 ayat 1 PKPU Nomor 13 Tahun 2018 disebutkan bahwa apabila perolehan suara pada kolom kosong lebih banyak dari perolehan suara pada kolom foto pasangan calon, KPU menetapkan penyelenggaraan pemilihan kembali pada pilkada periode berikutnya. Sementara di ayat 2 disebutkan "Pemilihan serentak berikutnya sebagaimana dimaksud pada ayat 1 dapat diselenggarakan pada tahun berikutnya atau dilaksanakan sebagaimana jadwal sesuai dengan ketentuan peraturan perundang-undangan."Pada akhirnya kotak kosong seakan blunder di alam demokrasi. Sesuatu yang tak demokratis bagai menampar wajah demokrasi. Sungguh sebuah ironi. Tambahan lagi ketika kotak kosong justru yang menang, beberapa konsekuensi tak terhindarkan. ${ }^{16}$

Ini semua harus menjadi perhatian kita bersama ketika kotak kosong seakan menjelma menjadi sebuah kekuatan yang menandakan bahwa proses berdemokrasi kita tidak bisa untuk dibodohi lagi, rakyat semakin pintar untuk menentukan pilihannya walaupun wujudnya tidak nyata.

Berbagai kecenderungan proses dan hasil Pemilukada tetap merupakan bahan kajian yang menarik. Kecenderungan proses pencalonan dan koalisi antar partai dalam mengajukan kandidat atau pasangan calon adalah salah satu fenomena paling menarik di balik penyelenggaraan Pemilukada di Indonesia. Daya tarik itu tidak hanya terletak pada kecenderungan yang berbeda dengan yang terjadi di tingkat nasional melainkan partaipartai yang secara ideologis sering dipandang sangat berbeda satu sama lain bahkan bisa saling berkoalisi dalam mangajukan pasangan kandidat dalam Pemilukada yang cenderung berbeda dengan hasil pemilu legislatif.

Sistem kehidupan berdemokrasi di Tanah Air terus mengalami perkembangan yang dinamis. Perbaikan demi perbaikan dilakukan dengan memetik pengalaman di masa lalu. Pun demikian dalam pelaksanaan pemilihan kepala daerah. Kemandekan hukum yang disebabkan tidak diperbolehkannya calon tunggal dalam pilkada dipecahkan Mahkamah Konstitusi. Pilkada tetap bisa berlanjut meski hanya ada satu pasangan calon yang maju. Hal itu kemudian diatur dalam Undang-Undang No 10 Tahun 2016 tentang Pilkada. Seyogianya proses pencalonan yang berujung pada calon tunggal merupakan kondisi kedaruratan. Sebuah kondisi ketika sudah benar-benar tidak ada calon lain yang layak. Namun, ternyata situasi yang sebetulnya darurat itu cenderung semakin banyak terjadi.

Namun Publik cukup bisa bernapas lega saat Undang-Undang Pilkada mengatur pilihan lain bagi warga selaku penentu akhir pemilihan kepala daerah. Calon tunggal harus mendapatkan lebih dari $50 \%$ suara untuk bisa terpilih. Pemegang hak suara boleh mencoblos kolom atau kotak kosong jika tidak ingin calon tunggal itu meraih kemenangan. Meski ada saluran 'kotak kosong, masyarakat sesungguhnya berada di posisi yang merugi. Ketika calon tunggal menang, pemimpin yang didapat belum tentu yang terbaik karena ketiadaan kompetisi. Sebaliknya, saat 'kotak kosong' menang, untuk sementara daerah dipimpin pejabat yang memiliki kewenangan terbatas. Pilkada ulang harus diselenggarakan hingga terpilih kepala daerah definitif. Lingkaran setan bisa tercipta karena calon tunggal yang kalah tetap boleh maju kembali menjadi calon. ${ }^{17}$

\section{METODE \\ Jenis Penelitian}

Penelitian ini menggunakan metode atau jenis penelitian yuridis normatif, yaitu pendekatan terhadap permasalahan dilakukan dengan mengkaji ketentuan mengenai kemenangan kotak kosong dalam pemilihan kepala daerah. Menggunakan pendekatan yuridis normatif oleh karena sasaran penelitian ini adalah hukum atau kaedah (norm). ${ }^{18}$

\section{Sumber Data}

Sebagai penelitian hukum normatif, penelitian ini menitik beratkan pada studi kepustakaan. Sumber bahan hukum yang digunakan dalam penelitian ini adalah data skunder melalui studi dokumen-dokumen, untuk memperoleh data yang diambil dari bahan kepustakaan, diantaranya adalah :

\section{Bahan Hukum Primer, ${ }^{19}$ yaitu bahan hukum yang mengikuti Perundang-undangan}

16 Deli Ana. Melawan Kotak Kosong, Ironi Pilkada 2018? http://www.voa-islam.com/read/citizensjurnalism/2018/07/05/58901/melawan-kotak-kosong-ironi-pilkada-2018/\#sthash.KyTvh2dy.dpbs. Diakses pada tanggal 25 September 2018.

${ }^{17}$ Senalince Mara, Demokrasi Kotak Kosong (Studi Kasus Pada Pemilukada Kota Jayapura tahun 2017). Jurnal Civic Education, Vol. 2 No. 1 Juni 2018. hal. 56.

${ }^{18}$ Soerjono Soekanto dan Sri Mamudji, Penelitian Hukum Normatif Suatu Tinjauan Singkat, Jakarta, PT. Raja Grafindo Persada, 1995.hal. 70

${ }^{19}$ Ronny Hanitijo Soemitro, Metode Penelitian Hukum dan Jurimetri, Jakarta, Ghalia Indonesia, 1990, hal. 53.
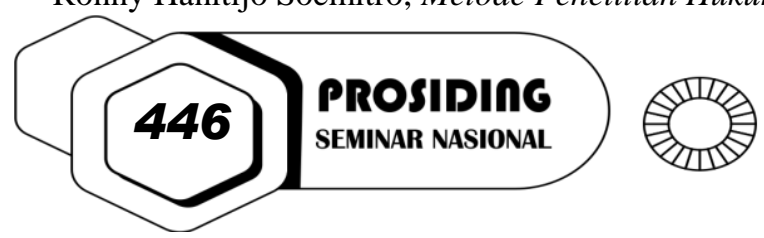
2. Bahan hukum sekunder, ${ }^{20}$ yaitu bahan hukum yang menjelaskan bahwa hukum primer, antara lain berupa tulisan atau pendapat pakar hukum dibidang waris.

3. Bahan hukum tersier, yaitu bahan-bahan yang sifatnya penunjang untuk dapat memberikan petunjuk dan penjelasan terhadap bahan hukum primer dan sekunder, seperti jurnal hukum, jurnal ilmiah, surat kabar, internet serta makalah-makalah yang berkaitan dengan objek penelitian. ${ }^{21}$

\section{Teknik Pengumpulan Data}

Untuk mendapatkan hasil yang objektif dan dapat dibuktikan kebenarannya serta dapat dipertanggung jawabkan hasilnya, maka data dalam penelitian ini diperoleh melalui alat pengumpulan data yang dilakukan dengan menggunakan cara Studi dokumen digunakan untuk memperoleh data sekunder dengan membaca, mempelajari, meneliti, mengidentifikasi dan menganalisis data sekunder yang berkaitan dengan materi penelitian.22

\section{Analisis Data}

Penelitian ini bersifat deskriptif. Data hasil penelitian yang berupa data hasil studi dokumen (data sekunder), dengan maksud untuk memaparkan apa yang dianalisis tadi secara sistematis dan menyeluruh untuk menjawab permasalahan yang diteliti sehingga dihasilkan kesimpulan dalam penelitian ini dengan menggunakan metode deduktif.

\section{HASIL DAN PEMBAHASAN \\ Fenomena Kotak Kosong}

Kotak kosong menjadi pemenang di beberapa daerah yang menggelar Pemilihan Kepala Daerah (Pilkada) Serentak Tahun 2018 pada 27 Juni lalu. Kemenangan kotak kosong versi hitung cepat atau quick count itu menimbulkan tanda tanya, bagaimana langkah selanjutnya?

Mengutip Pasal 54D ayat 1 Undang-Undang Nomor 10 Tahun 2016 tentang Pilkada Kepala Pusat Penerangan (Kapuspen) Kementerian Dalam Negeri (Kemendagri) Bahtiar menjelaskan, KPU Provinsi atau KPU Kabupaten/Kota menetapkan pasangan calon terpilih pada Pemilihan 1 (satu) pasangan calon sebagaimana dimaksud Pasal 54C, jika mendapatkan suara lebih dari 50\% dari suara sah. Jika perolehan suara pasangan calon kurang dari sebagaimana dimaksud pada ayat (1), pasangan calon yang kalah dalam Pemilihan boleh mencalonkan lagi dalam Pemilihan berikutnya, merujuk Pasal 54D ayat $2 .{ }^{23}$

Melawan kotak kosong dalam Pilkada sebenarnya memalukan, bukan justru membanggakan. Mengapa saya katakan demikian? Karena ada cara pandang mainstream bahwa melawan kotak kosong bermakna dominasi satu kandidat, baik popularitas maupun elektabilitas. Dominasi semacam ini, dalam kacamata personal sang kandidat, adalah sebuah "kehebatan". Bagaimana tidak, nyaris tak ada yang berani menantang lantaran superdominasi tersebut.

Dalam kacamata sang kandidat, melawan kotak kosong adalah sebuah indikasi ketangguhan yang berlebihan, sampai tak ada yang bernyali untuk bersaing dalam kontestasi. Padahal, Pilkada adalah salah satu mekanisme demokrasi yang sudah sedemikian rupa didesain agar semua pihak berkesempatan untuk ikut bertanding. Kemudian pertanyaannya, apakah demokrasi di tingkat lokal di mana Pilkada ternyata hanya mampu melahirkan satu pasangan calon dianggap gagal? Boleh jadi demikian.

Tapi, apakah perlu kita menyalahkan demokrasi? Toh selama ini demokrasilah yang kita jadikan justifikasi untuk menumbangkan segala rezim yang aneh-aneh. Demokrasi kita jadikan peluru-peluru untuk menyalahkan dan membenarkan banyak pihak. Dan, demokrasi pula yang kita jadikan landasan untuk menjalankan Pilkada tersebut. Jadi, agak kurang etis jika kita salahkan. Jika masih tetap bersemangat untuk mencari yang salah, maka sebaiknya salahkan saja kotak kosong tersebut, sepaket dengan lawan dan partai-partai yang mendukungnya.

Lebih dari itu, saya kira kita memang perlu melirik demokrasi dalam kacamata pemerataan. Apakah demokrasi elektoral sudah menyebar secara merata ke seluruh Indonesia dalam makna nan substantif atau belum. Karena ternyata dari data yang ada, ada sekira 19 daerah yang akan melangsungkan Pilkada kali ini

\footnotetext{
${ }^{20}$ Ibid, hal. 55 .

${ }^{21}$ Soerjono Soekanto dan Sri Mamudji, Op. Cit, hal. 14.

${ }^{22}$ Soerjono Soekanto, Pengantar Penelitian Hukum, Jakarta, Universitas Indonesia Press, 1986, hal. 21.

23 M. Agus Yozami, Ini Aturan Bila Kotak Kosong Menang Pilkada Serentak 2018, https://www.hukumonline.com/berita/baca/lt5b35ce0bc9e9f/ini-aturan-bila-kotak-kosong-menang-pilkadaserentak-2018, , diakses pada tanggal 24 Januari 2019.
} 
mengalami defisit calon pemimpin. Di setiap daerah tersebut, satu pasangan kandidat digadang-gadang akan berhadapan head to head dengan kotak kosong.

Lihat saja, Komisi Pemilihan Umum (KPU) telah memastikan Pilkada 2018 di 19 daerah hanya akan diikuti satu pasang calon atau calon tunggal. Jumlah calon tunggal lawan kotak kosong pada Pilkada tahun ini meningkat dari Pilkada 2017. Pada tahun lalu, dari 101 daerah yang menggelar pilkada, hanya ada sembilan daerah yang diikuti satu pasangan calon. Memang, dapat dipahami mengapa terjadi peningkatan. Salah satunya karena jumlah daerah yang mengadakan pun jauh lebih banyak dibanding dua pilkada serentak sebelumnya.

Lantas apa kira-kira yang dirasakan oleh pasangan calon yang ternyata harus berhadapan dengan kotak kosong? Pertama, pastilah bahagia karena kemenangan langsung ada di depan mata. Tidak perlu banyak pengorbanan politik lagi, terutama logistik. Kedua adalah bangga. Merasa tak tertandingi. Merasa sebagai the only king in the town. Sebenarnya lucu juga, dalam sebuah mekanisme demokrasi justru yang lahir adalah calon raja.

Tak ada yang berani menyemplungkan diri untuk bertanding dengan mereka karena yang dilawan adalah raja, alias yang merajai daerah tersebut. Bedanya tipis saja, dalam kerajaan tak mengenal wakil raja. Tapi, di dalam demokrasi elektoral lokal, kandidat raja sepaket dengan wakilnya. Dan, jangan-jangan semua inkubator kepemimpinan di daerah tersebut diketuai oleh mereka pula. Atau, setidaknya, kandidat tunggal tersebut satusatunya patron politik untuk semua pemimpin organisasi-organisasi (inkubator kepemimpinan) di daerah tersebut. Ini baru sekedar asumsi saya alias sekedar "jangan-jangan" saja. Semoga tidak.

Dan, yang ketiga...ya, semestinya ada jenis perasaan ketiga yang dirasakan oleh kandidat yang akan berhadapan dengan kota kosong, yakni malu. Kata yang saya asumsikan di awal tulisan ini. Mengapa? Karena pertandingan yang seru adalah pertandingan yang dilakoni oleh dua atau beberapa pihak dengan kapasitas kemampuan yang hampir sama (level playing field). Ibarat memakai logika komparatif, harus apple to apple.

Nah, lantas jika kandidat di 19 daerah tersebut harus melawan kotak kosong, maka dalam logika komparatif di atas, sang kandidat pun sebenarnya berbeda tipis dengan kotak kosong yang menjadi lawannya. Atau, jika mau sedikit menyopankan bahasanya, maka bisa dimaknai kotak kosong selevel dengan para kandidat di 19 daerah tadi.

Tampaknya secara logika boleh jadi tak terlalu salah, sekalipun saya hakul yakin tak ada satu pun dari kandidat di 19 daerah tersebut bersedia mengamininya. Tapi, ya begitulah. Secara logika komparatif, pemenangnya sebenarnya adalah kotak kosong itu sendiri. Pasalnya, sekalipun sebenarnya pemenangnya secara meyakinkan adalah pasangan tunggal tersebut, toh level lawannya hanya kotak kosong. Jadi ya sama sajalah. ${ }^{24}$

\section{Kemenangan Kotak Kosong Dalam Pemilihan Kepala Daerah}

Tanggal 27 Juni 2018, Indonesia menyelenggarakan pemilihan kepala daerah (pilkada) serentak yang berlangsung 171 daerah provinsi, kabupaten dan kota. Pilkada serentak kali ini merupakan pilkada serentak gelombang ketiga sebelum menuju pada 2027 saat di Indonesia hanya ada dua pemilihan umum (pemilu), yaitu pemilu nasional serentak (memilih legislatif, presiden dan wakil presiden) dan pemilihan kepala daerah (pilkada) serentak.

Pilkada serentak gelombang pertama berlangsung 9 Desember 2015 dan pilkada serentak gelombang kedua 15 Februari 2017. Pada pilkada 27 Juni 2018 muncul fenomena menarik, adanya pilkada yang hanya diikuti satu pasangan calon kepala daerah atau calon tunggal dengan jumlah yang meningkat.

Berdasarkan data Komisi Pemilihan Umum (KPU) pada pilkada 2018 ada 16 pasangan calon (paslon) kepala daerah-wakil kepala daerah akan melawan kolom kosong atau kerap disebut "kotak kosong" yang berkonsteasi di 16 daerah kabupaten dan kota. Jumlah pasangan calon tunggal kali ini mengalami peningkatan dibanding dua gelombang pilkada serentak sebelumnya. Pilkada serentak 2015 hanya ada tiga daerah dengan calon tunggal, yaitu pilkada Kabupaten Tasikmalaya, pilkada Kabupaten Blitar, dan pilkada Kabupaten Timur Tengah Utara.

Kemudian pada pilkada serentak gelombang kedua 2017 jumlah itu meningkat menjadi sembilan daerah dengan calon pasangan tunggal. Pada Pilkada gelombang ketiga 2018 kembali meningkat. Ini fenomena apa dengan pilkada calon tunggal melawan kotak kosong/kolom kosong yang jumlahnya mengalami peningkatan?

Fenomena pasangan calon tunggal tidak bisa dihindari karena diatur dalam UU Nomor 10 Tahun 2016 tentang Perubahan Kedua atas Undang-Undang Nomor 1 Tahun 2015 tentang Penetapan Peraturan Pemerintah

\footnotetext{
${ }^{24}$ Jannus T. Siahaan, Melawan Kotak Kosong Dalam Pilkada, https://news.detik.com/kolom/3842608/melawankotak-kosong-dalam-pilkada. Diakses pada tanggal 4 Oktober 2018.
}
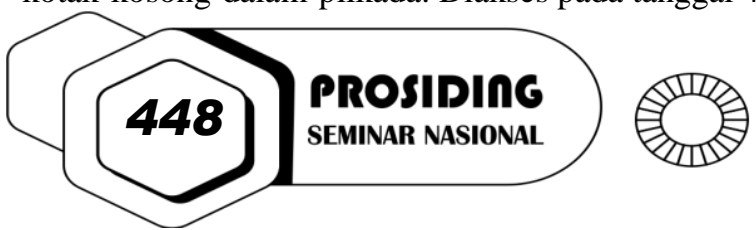
Pengganti Undang-Undang Nomor 1 Tahun 2014 tentang Pemilihan Gubernur, Bupati, Dan Wali Kota menjadi Undang-Undang.

Kemudian Peraturan Komisi Pemilihan Umum (PKPU) No 11 Tahun 2016 mengatur pilkada calon tunggal dalam Pasal $11 \mathrm{~A}$, mengatur surat suara pada pemilihan satu pasangan calon memuat dua kolom yang terdiri atas satu kolom yang memuat foto dan nama pasangan calon dan kolom kosong yang tidak bergambar atau lebih populer dengan istilah "kotak kosong." PKPU No.8 Tahun 2017 juga mengatur tentang sosialisasi "kolom kosong."

Saat masa kampanye di Prabumulih muncul Posko kotak kosong. Posko ini berdiri dengan diprakarsai barisan relawan kotak kosong (Koko). Sejak April 2018 sudah berdiri beberapa posko Koko. Kehadiran posko tersebut menimbulkan reaksi beragam, tidak hanya dari masyarakat awam tapi juga mendapat respon dari para wakil rakyat di parlemen mengharapkan agar tidak memilih kotak kosong pada Pilkada 2018.

Lantas bagaimana jika ada yang memilih kolom kosong dalam kertas surat suara yang tidak ada foto pasangan calon? Tidak bolehkah melakukan kampanye dengan tagline "pilih kotak kosong" atau kolom kosong? Ada juga menilai memilih kotak kosong/kolom kosong sama artinya dengan tidak memilih atau golput dan tidak sah.

Untuk yang terakhir, memilih kotak kosong/ kolom kosong dalam pilkada menurut anggota Komisi Pemilihan Umum (KPU) Wahyu Setiawan, "Memilih kotak kosong berbeda dengan golput. Suara yang diberikan masyarakat ke dalam kotak kosong merupakan suara sah dengan nilai yang sama dengan mereka yang memilih seorang pasangan calon."

Bagaimana dengan kampanye pilih kotak kosong/ kolom kosong? Jawabannya ada PKPU No.8 Tahun 2017. Kampanye memilih kotak kosong pada pilkada terjadi di Kota Prabumulih, Sumatera Selatan (Sumsel) yang hanya diikuti satu pasangan calon, yaitu Ridho Yahya-Andriansyah Fikri. Kampanye memilih kota kosong dilakukan Barisan Relawan Kotak Kosong (Koko). Kampanye memilih kotak kosong/kolom kosong dalam kertas suara pilkada bukan suatu yang dilarang atau melanggar dari regulasi pilkada.

Kemudian jika hasil pilkada dengan calon tunggal yang ditetapkan KPU pemenangnya adalah kotak kosong bagaimana selanjutnya? KPU telah menetapkan, jika pada pilkada serentak 2018 yang memenangkan pemungutan suara pilkada adalah kotak kosong akan akan dilaksanakan pilkada ulang.

Pilkada dengan calon tunggal sudah mulai muncul saat pilkada langsung 2006 di Kabupaten Jepara, kemudian menjadi polemik pada Pilkada 2015. Mahkamah Konstitusi (MK) memberikan putusan atas uji materiil UU Nomor 8 Tahun 2015 dengan putusan No. 100/PUU-XIII/2015 MK membuka jalan beberapa daerah yang memiliki satu pasang calon kepala daerah untuk tetap menyelenggarakan pilkada pada tahun 2015.

Pilkada yang hanya terdiri dari satu pasang calon apakah masuk dalam kategori demokratis atau tidak? Menurut Michael P McDonald dan John Samples mengungkapkan, pemilu-pemilu yang demokratis adalah mengenai pilihan di antara kandidat-kandidat yang berkompetisi dan isu yang mereka akan laksanakan jika terpilih. Ada kata "kandidat-kandidat" artinya "jamak" atau lebih dari satu. Dengan demikian, pemilu yang demokratis identik dengan terdiri dari minimal dua kandidat.

Tapi ada juga yang mengatakan pilkada dengan calon tunggal tetap demokratis karena konstituen diberi ruang untuk tidak memilih calon tunggal tersebut melalui mekanisme kotak kosong/ kolom kosong seperti pilkada serentak 2018.

Mengapa di 16 daerah tersebut hanya ada calon tunggal? Ada beberapa faktor yang mempengaruhi fenomena calon tunggal tersebut. Penelitian menyebutkan fenomena calon tunggal terjadi karena adanya mahar politik yang mahal dari partai politik. Regulasi pilkada di Indonesia menetapkan calon kepala daerah diusung oleh partai politik atau beberapa partai politik selain adanya calon independen.

Faktor lainnya karena partai politik di daerah dinilai belum mampu menjalankan fungsi kaderisasi dan rekrutmen politik dalam mengusung calon kepala daerah. Kaderisasi dan rekrutmen politik itu melekat pada fungsi utama partai politik yang seharusnya mampu melahirkan figur-figur yang kuat secara politik.

Partai politik seharusnya menjadi tempat bagi warga negara untuk berpartisipasi dalam pengelolaan kehidupan bernegara dan memperjuangkan kepentingannya di depan penguasa. Namun, secara praktis kondisi partai-partai politik di negara demokrasi belum dapat melaksanakan fungsinya secara optimal. Indonesia merupakan salah satu contohnya.

Faktor lain menyebabkan muncul calon tunggal adalah aturan dalam undang-undang mengenai syarat dukungan, terutama bagi calon perseorangan yang tidak mudah dipenuhi. Pilkada dengan calon tunggal bukanlah kontestasi politik yang bagus, karena kurangnya persaingan meraih kekuasaan yang seharusnya 
terjadi. Fenomena pilkada calon tunggal yang terus meningkat jumlahnya menjadi kontestasi demokrasi yang tidak ideal. 25

Peraturan mekanisme pemilihan gubernur, bupati, dan walikota tertuang dalam Undang-Undang No. 8 Tahun 2015 yang kemudian diperbaharui menjadi Undang-Undang No.10 Tahun 2016. Di mana Komisi Pemilihan Umum (KPU) menetapkan sekurangnya dua pasangan calon (paslon) sebagai peserta pilkada. Sebagaimana dijelaskan pada Pasal 54 ayat (5) Peraturan KPU No. 12 Tahun 2015, KPU menafsirkan bahwa jika hanya terdapat satu paslon atau tidak ada paslon yang mendaftar sampai dengan berakhirnya masa pendaftaran, maka KPU Provinsi atau KPU Kabupaten/Kota menetapkan keputusan penundaan seluruh tahapan. Dan, pemilihan di daerah tersebut diselenggarakan pada pilkada serentak berikutnya.

Apa yang menjadi problem saat ini ialah fenomena lawan kotak kosong semakin menguat, dan menjadi tanda tanya besar mengapa hal tersebut terjadi. Sebab, dalam suatu sistem demokrasi, di mana kesempatan tersebut terbuka sedemikian lebarnya tapi justru yang terjadi adalah menyusutnya calon kepala daerah.

Dalam kata "demokrasi" sejatinya dibayang-bayangi oleh kata "rakyat". Kedaulatan rakyat menjadi mimpi indah bagi suatu bangsa yang baru saja transisi dari kuasa otoritarian menuju suatu tatanan yang berkeadilan. Serta, menjadi petanda pula bagi lahirnya jalan konsolidasi rezim demokratis yang salah satu petandanya ialah pemilihan umum secara langsung. Namun, ketika fenomena calon tunggal melawan kotak kosong mengalami peningkatan dan ternyata pemilih kotak kosong pun tidak sedikit jumlahnya, sepertinya perlu kita merefleksikan kembali soal bagaimana kata "demokrasi" ini dimaknai.

Sudah saatnya partai politik berbenah diri. Banyaknya pencoblos kotak kosong seolah menjadi bahasa isyarat bahwa kehendak rakyat lebih menginginkan sosok pemimpin yang lebih aspiratif dan berpihak padanya. Atau, kotak kosong seolah mimpi yang menjadi nyata saat kebuntuan elektoral semakin tampak dampaknya.

Di sinilah perlunya evaluasi mendalam pada setiap partai politik. Partai politik harus betul-betul kembali mengevaluasi proses jalannya kaderisasi partai, dari ideologisasi bahkan sampai di tataran implementasi ideologi. Sehingga, yang terjadi bukan justru malah sebaliknya yakni serampangan menaruh calon; pokoknya asal terkenal di publik, punya elektabilitas tinggi dan tentu yang tunduk pada elit partai.

Kepemimpinan di setiap daerah tidak bisa dan bahkan tidak boleh dijalankan oleh mereka yang gagap terhadap falsafah demokrasi. Jika pemerintahan adalah alat untuk mensejahterakan rakyat, dan demokrasi membawa semangat ke arah kedaulatan rakyat, bagaimana mungkin suatu daerah dipimpin oleh pemimpin defisit akal sehat yang tentu lahir dari rahim partai politik?

Calon tunggal dan kotak kosong hanya satu dari sekian banyak tantangan membangun demokrasi, dan pemilihan kepala daerah hanyalah instrumen dalam menjalankan proses bernegara. Namun, yang menjadi tugas setiap warga negara ialah ada pada pasca pemilihan tersebut yakni mengkonsolidasikan kekuatan bersama untuk mengontrol jalannya sistem dan kebijakan yang ada, menjadi penekan atas pemenuhan hak asasi manusia, menjadi pengingat kala pemerintahan keluar dari khittah-nya. ${ }^{26}$

\section{PENUTUP}

\section{Simpulan}

Kemenangan kotak kosong merupakan sebuah fenomena langka dalam sebuah proses demokrasi di Indonesia, tapi itulah yang terjadi. Berdasarkan data yang ada bahwa dari tahun ketahun fenomena ini terus meningkat, ada dua hal yang menjadi penyebabnya yaitu beberapa partai politik didaerah yang belum mampu menjalankan fungsi kaderisasi yang baik dan undang undang mengenai syarat dukungan terutama bagi calon perseorangan yang tidak mudah untuk dipenuhi.

\section{Saran}

Untuk meminimalisir kehadiran kotak kosong dalam pemilihan kepala daerah harusnya partai politik mempersiapkan kaderisasi secara bertahap agar supaya pada saat tiba pencalonan tidak kelabakan lagi mencari siapa kader yang terbaik, kemudian pemerintah dalam hal ini juga harus memikirkan tentang syarat regulasi yang harus dipenuhi oleh calon persorangan agar supaya tidak membuat para calon perseorangan ini mudah untuk memenuhinya.

\footnotetext{
${ }^{25}$ Maspriel Aries. Pilkada Kotak Kosong 2018. https://republika.co.id/berita/kolom/fokus/18/06/27/payvc8396pilkada-kotak-kosong-2018. Diakses pada tanggal 26 September 2018.

26 Abdurrachman Sofyan, Pesan di Balik Kotak Kosong Pilkada, https://news.detik.com/kolom/d4087617/pesan-di-balik-kotak-kosong-pilkada, diakses pada tanggal 4 Oktober 2018.
}
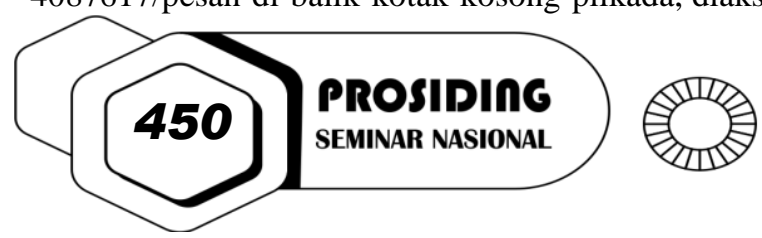


\section{DAFTAR PUSTAKA}

\section{Buku}

Soerjono Soekanto dan Sri Mamudji, 1995, Penelitian Hukum Normatif Suatu Tinjauan Singkat, Jakarta, PT. Raja Grafindo Persada.

Soerjono Soekanto, 1986, Pengantar Penelitian Hukum, Jakarta, Universitas Indonesia Press,

Ronny Hanitijo Soemitro, 1990, Metode Penelitian Hukum dan Jurimetri, Jakarta, Ghalia Indonesia,

\section{Jurnal}

Siti Dwi Puspita sari. Peran AKDPP (Aliansi Kawal Demokrasi Pilkada Pati) dalam Kemenangan Kotak Kosong di Desa Gajahmati dan Desa Maitan pada Pilkada Kabupaten Pati Tahun 2017. Jurusan IImu Pemerintahan Fakutas IImu Sosial dan IImu Politik Universitas Diponegoro.

Senalince Mara, Demokrasi Kotak Kosong (Studi Kasus Pada Pemilukada Kota Jayapura tahun 2017). Jurnal Civic Education, Vol. 2 No. 1 Juni 2018.

\section{Internet}

Abdurrachman Sofyan, Pesan di Balik Kotak Kosong Pilkada, https://news.detik.com/kolom/d-4087617/pesan-dibalik-kotak-kosong-pilkada, diakses pada tanggal 4 Oktober 2018.

Deli Ana. Melawan Kotak Kosong, Ironi Pilkada 2018? http://www.voa-islam.com/read/citizensjurnalism/2018/07/05/58901/melawan-kotak-kosong-ironi-pilkada-2018/\#sthash.KyTvh2dy.dpbs. Diakses pada tanggal 25 September 2018.

Jannus T. Siahaan, Melawan Kotak Kosong Dalam Pilkada, https://news.detik.com/kolom/3842608/melawankotak-kosong-dalam-pilkada. Diakses pada tanggal 4 Oktober 2018.

Maspriel Aries. Pilkada Kotak Kosong 2018. https://republika.co.id/berita/kolom/fokus/18/06/27/payvc8396pilkada-kotak-kosong-2018. Diakses pada tanggal 26 September 2018.

Mohamad Rizal. Kemenangan Kotak Kosong jadi Sejarah Baru di Pilkada http://pilkada.metrotvnews.com/newspilkada/DkqL198b-kemenangan-kotak-kosong-jadi-sejarah-baru-di-pilkada. Diakses pada tanggal 23 September 2018.

M. Agus Yozami, Ini Aturan Bila Kotak Kosong Menang Pilkada Serentak 2018, https://www.hukumonline.com/berita/baca/t5b35ce0bc9e9f/ini-aturan-bila-kotak-kosong-menang-pilkadaserentak-2018, , diakses pada tanggal 24 Januari 2019.

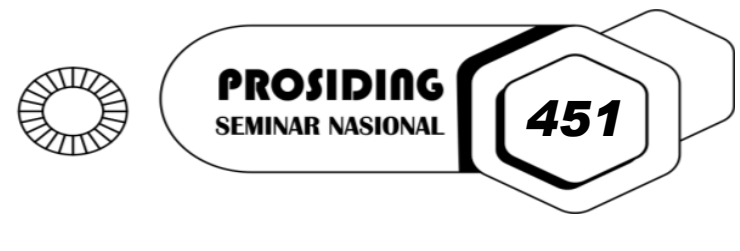

